\title{
STAKEHOLDER MAPPING IN SELECTED CZECH REGIONS
}

MAPOVÁNÍ STAKEHOLDERS VE VYBRANÝCH REGIONECH ČESKÉ REPUBLIKY

\section{ING. MARTIN LUŠTICKÝ ${ }^{1}$}

\section{BC. Pavla ZaUnMüllerová ${ }^{1}$ \\ ING. LUCIE VÁCHOVÁ ${ }^{1}$}

\author{
PhDr. Jaroslava KADEŘÁBKOVÁ, CSc. ${ }^{2}$ \\ ${ }^{1}$ Katedra managementu ${ }^{1}$ Department of Management \\ Fakulta managementu Faculty of Management \\ Vysoká škola ekonomická v Praze University of Economics Prague \\ $\triangle$ Jarošovská 1117, 37701 Jindřichův Hradec, Czech Republic \\ E-mail:Lusticky@fm.vse.cz,xzaup00@fm.vse.cz,Vachova@fm.vse.cz \\ ${ }^{2}$ Katedra regionálnich studii $\mid{ }^{2}$ Department of Regional Studies \\ Národohospodářrká fakulta Faculty of Economics \\ Vysoká škola ekonomická v Praze University of Economics Prague \\ Nám. W. Churchilla 4, 13067 Praha, Czech Republic \\ E-mail:kaderj@vse.cz
}

\begin{abstract}
Annotation
Tourism has a significant potential to have a beneficial effect on all three pillars of regional development - economic, social and environmental. From this point of view the managing of tourism development can be considered as a tool of the regional policy which can be suitable for an efficient reducing of regional disparities. This paper is focused on collaboration tourism planning within the framework of sustainable competitive advantage which can be reached by an engagement of regional stakeholders in the planning process - primarily into the phase of strategy implementation and control. The aim of this paper is to realize the first phase of Stakeholder Audit which includes mapping of regional stakeholders. The paper utilizes information from regional governments' representatives and it maps regional stakeholders in travel \& tourism sector on a basis of the main principle of the Stakeholder Circle method. It analyses the stakeholders with the help of three widely used attributes which are modified with respect to specific condition of tourism sector. By the means of those attributes it determines the Stakeholder Index and identifies the most important generic stakeholders groups which should be engaged in the process of tourism development planning.
\end{abstract}

Key words

tourism, stakeholder, mapping, Stakeholder Circle

\section{Anotace}

Cestovni ruch má významný potenciál působit na všechny tři pilíre regionálního rozvoje ekonomický, sociálni a ekologický pilír. Z tohoto úhlu pohledu může být řizeni jeho rozvoje vnimáno jako nástroj regionálni politiky, díky kterému lze účinně působit na snižováni regionálních disparit. Př́spěvek se zaměruje na kooperativni plánováni rozvoje cestovniho ruchu v kontextu dlouhodobě udržitelné konkurenčni výhody, které je možné dosáhnout zapojenim regionálnich aktérů (stakeholders) do plánovacího procesu, predevšim do fáze implementace a kontroly strategie. Cílem př́spěvku je realizovat úvodni fázi tzv. Stakeholder Audit, spočivajici ve zmapováni regionálních 
aktérů. Př́spěvek využivá informaci od zástupců regionálni veřejné správy a na základě principu metody Stakeholder Circle mapuje regionálni stakeholders v cestovním ruchu. Provádí jejich analýzu s pomoci tři nejčastěji uživaných charakteristik, které jsou modifikovány sohledem na specifika cestovniho ruchu. S využitím těchto charakteristik stanovuje tzv. Stakeholder Index a identifikuje nejdůležitějši generické skupiny stakeholders, které by měly být do procesu plánováni rozvoje cestovního ruchu zapojeny.

\section{Kličová slova}

cestovni ruch, stakeholder, mapování, Stakeholder Circle

JEL classification: $R 58$

\section{Introduction}

One of the areas the recent regional policy is focused on is supporting of tourism development that can be considered a specific tool of regional development (Tittelbachová, 2006). Tourism contributes to both regional and local economy stability, especially because of its positive multiplier effect. Nejdl (2011) characterizes the benefits of tourism as positive outcomes of processes in territory that have influence on development of new possibilities for local inhabitants, increase utilities of local economy and decline select negative phenomena. At the same time he points out that usually these benefits are difficult to be expressed numerically and in most cases there exist only qualified estimates instead. Tourism has multidimensional character and so it intervenes in many economic branches but it has effect even in both social and ecological spheres (Hall, 2008; Cooper et al., 2008).

Tourism as well as other economic branches faces competitive pressures which grow significantly in recent global society (Ritchie, Crouch, 2003). This is why all the European Union, national and regional governments try to find ways aimed at increase in competitiveness in tourism. One of the widely recognized factors of competitiveness is the strategic planning and subsequent implementation and monitoring of the strategies (Enright, Newton, 2005; Dwyer, Kim, 2003; Ritchie, Crouch, 2003). How Pechlaner a Saurwein (2002) mention the considerable attention is paid to strategic planning, but the process of implementation is not examined in such a detailed way. Nevertheless both realization and subsequent monitoring are crucial for success of a strategy as a whole; without them the entire process loses its purpose (Poister, Streib, 1999). Unfortunately in the Czech practice it often happens that despite the existence of strategy its practical realization fails. Vacík (2006) remarks that a weak point of recent public service management is a shift to the implementation phase.

The same situation can also be seen in the sphere of implementation and monitoring of the tourism development strategies in cooperation with the regional stakeholders. In development strategies, only insufficient space is devoted to the phase of implementation, and conditions for its realization are often prepared inadequately. It is reflected in practice - the cooperation between public administration and the regional stakeholders often fails or it exists only on a formal basis. Nevertheless the importance of involvement of the regional stakeholders in the strategy implementation process is emphasized by a number of authors (Ritchie, Crouch, 2003; Hall, 2008). Some of them consider it as a basic assumption for achievement of a sustainable competitive advantage (Byrd, Cárdenas, Greenwood, 2008).

Buhalis (2000) points out that managing of tourism with an involvement of the regional stakeholders is extremely difficult for a destination management. Quite a number of stakeholders groups with various interests, complex mutual relations and different willingness to cooperate within realization of the strategy occur in a given destination. Nevertheless the destination management should not resign to its coordination and realization role. This is the only way how the destination management can effectively influence the sustainable development of tourism (Buhalis, 2000; Ritchie, Crouch, 2003; Nejdl, 2011). The necessary first step rests in an identification of the key regional stakeholders to 
which an attention of the destination management must be paid (Medeiros de Araujo, Bramwell, 1999).

For this purpose quite a number of methods for mapping and evaluation of the stakeholders can be found, as summarized for instance by Medeiros de Araujo and Bramwell (1999) or by Částek (2010). Most of the methods use graphical representation in the form of maps of the regional stakeholders according to their attributes. In this paper the Stakeholder Circle is used as a specific method for mapping and analysing the stakeholders. This method has relatively well-developed methodology of its implementation that can be modified even for conditions of the strategic analysis in tourism. Its output is not only the graphical representation of the regional stakeholders according to three key attributes, but also their arrangement according to their importance to tourism government based on calculation of the Stakeholder Index. It enables to describe the stakeholders in greater detail and answer the key questions introduced by Mitchell et al. (1997): "Who is the regional stakeholder?" and "Whom the destination management should pay attention to?".

\section{Research Objective and Methodology}

The main target of this research is an implementation of a comprehensive stakeholder audit in selected Czech regions. The audit will be focused on cooperation between public administration and the regional stakeholders in the process of implementation of the tourism development strategies. The secondary object of this research is a transfer of good practices from selected region of Great Britain. These practices will react to the results of the audit, enable an improvement of cooperation and thus may contribute to increasing competitiveness of the Czech regions. The following figure briefly describes the research methodology.

Fig. 1: Scheme of the Research Methodology

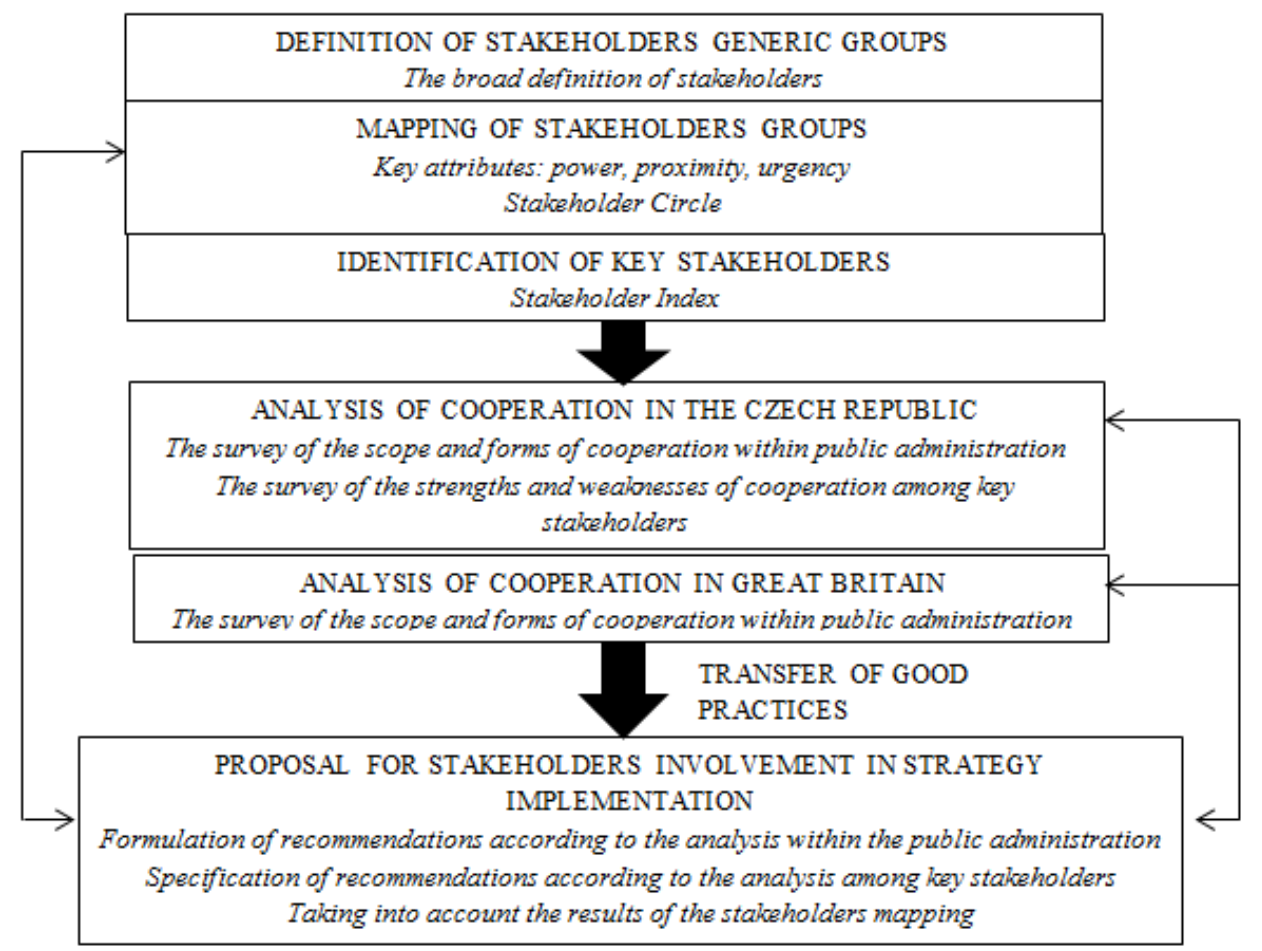

Source: own elaboration

This paper must be understood as a general introduction to the research mentioned above. It is focused on the first phase of the research - the mapping of regional stakeholders. However the quintessence of this phase is mainly a description, it represents an inevitable phase for consecutive research. Its main purpose is to test the drafted methodical procedure and show the way for the next research phases. Characterizing of the regional stakeholders and their differentiation according to their importance can 
be established as a primary target of this phase. In such a way the appropriate partners for the field survey will be identified. This survey will be focused on an assignment of the real state of cooperation in the field of implementation of the tourism development strategy. The secondary target is a description of the main lines of cooperation which will be subjects of more detail investigation in the next phase of the research.

In the first step it is necessary to identify the basic generic groups of destination's stakeholders. For this reason, the broad definition of the stakeholders is used. It considers the stakeholders as those "who can affect the achievement of the organization's objectives or who are affected by the achievement of the organization's objectives" (Č́stek, 2010, s. 25). The stakeholders are similarly defined by Byrd, Cardenas and Greenwood (2008) who specify the definition to the conditions of tourism. Thus we consider the stakeholders to be such organizations which operate in region influencing by the strategy, and which participated in strategy elaboration, or which are affected by this strategy. Using Byrd, Cardenas and Greenwood (2008) approach together with other sources (Buhalis (2000); Yoon (2002), Crouch (2010)) the following groups of stakeholders are compiled:

- Public Administration: the regional authorities, the micro-regions, the municipalities

- Private Sector: the destination organizations, the regional tourism organizations, the regional development agencies

Those broad-based groups of stakeholders are not suitable for the practical implementation of the research. Therefore, it is necessary to narrow them by using the appropriately selected attributes. For this aim it is possible to use the mapping techniques which usually describe two or three attributes. The attribute of strength / power is the most frequently appearing stakeholder's characteristics. It is usually followed by the attribute of attitude, interest, proximity, or legitimacy. Mitchell, Agle and Wood (1997) add the attribute of urgency in their three-dimensional model. The Stakeholders Circle method employs these attributes (Walker, Shelley, Bourne, 2008): the stakeholders' influence on the project, involvement of the stakeholders in the project and the urgency of the stakeholders. With regard to the specifics of tourism these characteristics were modified to this set of attributes:

- Importance (I) - the importance of the stakeholders for tourism development

- Proximity $(\mathrm{P})$ - the intensity of cooperation with the stakeholders in tourism development

o Legitimacy (L) - the formality of cooperation with the stakeholders

- Urgency (U) - the need of the stakeholders involvement in the process of strategy implementation; decomposition into two subordinate attributes

o Support (S) - share of the stakeholders in the strategy implementation process

o Willingness (W) - interest of the stakeholders in an improvement of cooperation

The attribute of urgency is calculated according to the following formula:

$$
U=\frac{S \times W}{16} \times 4
$$

On the basis of the Stakeholder Circle methodology the qualitative scale is defined for each attribute. This scale is expressed numerically in the range of 1-4 points. The logic of this scale is simple - an intensity of the attribute increases with increasing number of points. The necessary information is obtained through structured interviews with the representatives of regional governments. In the testing phase of the research the respondents are representatives of the South Bohemia Tourism Authority. The output is a graphical representation of local stakeholders groups in the form of circular sectors. The Stakeholder Circle methodology was simplified in such a way that it is possible to construct the graph manually, without the necessity of specialized software. In addition to the graphical representation, it is possible to compute the Stakeholder Index by the following formula:

$$
S I=\sum(I, P, U)
$$

This index allows ranking the stakeholders groups with respect to the importance based on selected attributes. Thus it indicates those regional stakeholders the public administration should focus on within the strategy implementation. It identifies the key groups which should be involved in tourism development process in the region. The next phase of the research will be targeted on particular 
representatives of given key groups. Its aim will be to gather information about weaknesses and strengths of the current cooperation process from the key stakeholders' points of view.

\section{Regional Stakeholders Mapping}

With the help of the representatives of the South Bohemia Tourism Authority it was possible to verify the validity of proposed generic groups of stakeholders. All the stakeholders groups proved to be correctly specified. The departments of the regional authority, the municipalities and the regional tourism organizations entirely meet our definition of the stakeholders. The regional development agencies and the destination organizations meet the definition less intensively. Only the micro-regions can be considered as the destination stakeholders in a limited way.

Stakeholder mapping by the means of the Stakeholder Circle methodology was made with the help of three key attributes - importance, proximity and urgency. Those attributes were evaluated on $1-4$ point scale which was used for each generic group of stakeholders. The important part of the stakeholder mapping process is a computing of the attribute of urgency according to the formula nr. 1. The evaluation's results are described in the table nr. 1. The attribute of legitimacy is considered as an additional statement of the attribute of proximity and it is marked by the grey hatching.

Tab. 1: Stakeholders Attributes

\begin{tabular}{|l|r|r|r|r|r|}
\hline & \multicolumn{6}{|c|}{ Stakeholders Attributes } \\
\cline { 2 - 7 } Generic Groups of Stakeholders & $\begin{array}{c}\text { Importanc } \\
\mathbf{e}\end{array}$ & $\begin{array}{c}\text { Proximit } \\
\mathbf{y}\end{array}$ & $\begin{array}{c}\text { Urgenc } \\
\mathbf{y}\end{array}$ & $\begin{array}{c}\text { Suppo } \\
\mathrm{rt}\end{array}$ & Willingness \\
\hline Departments of Regional Authority & 4 & 4 & 4,0 & 4 & 4 \\
\hline Micro-regions & 2 & 2 & 1,0 & 2 & 2 \\
\hline Municipalities & 4 & 3 & 3,0 & 3 & 4 \\
\hline Destination Organizations & 3 & 2 & 1,5 & 3 & 2 \\
\hline Tourism Organizations & 3 & 3 & 3,0 & 3 & 4 \\
\hline Regional Development Agencies & 3 & 2 & 2,3 & 3 & 3 \\
\hline
\end{tabular}

The values of the attributes strongly correlate with a perception of the groups as the regional stakeholders. The organizations from the sphere of public administration, represented by the departments of the regional authority and selected municipalities in the South Bohemia Region, are considered to be the most important stakeholders participating in tourism development. Other stakeholders groups influence tourism development in a less important way. The most intensive cooperation on tourism development is running with the departments of the regional authority - the Department of Marketing and Tourism, the Department of Culture, the Department of Regional Development. The intensive cooperation is also running with competent departments of the municipal offices (mainly on the level of former district towns). In both cases the cooperation is formalized thanks to regular meetings. The South Bohemia Tourism Authority perceives the regional tourism organizations as important stakeholders (e.g. Association of Hotels and Restaurants, ATIC, Confederation of Commerce and Tourism). Unfortunately, the cooperation with these subjects is still not formalized. The regional development agencies are an important partner for implementation of the strategy but the intensity of relationships is little bit lower. The evaluation of the destination organizations is slightly surprising. Although they are perceived as the regional stakeholders, they concentrate its attention to the development of specific area (e.g. Český Krumlov, Lipno Lake) and thus the cooperation on the regional level is not too intensive.

The facts mentioned above are well-illustrated by the value of the urgency attribute. The key subjects of cooperation are the departments of the regional authority which have a significant role in the strategy implementation and which also have an interest in further development of cooperation. It is possible to view the municipalities and the regional tourism organization in a similar way. The regional development agencies and the destination organizations also participate in the 
implementation process of the strategy. However they declare lower willingness for cooperation and thus the need for their involvement into the process is not so intensive. The micro-regions are the outsiders from this point of view. Their attributes have the lowest values in all cases, so the microregions are not significant destination stakeholders for the South Bohemia Tourism Authority.

The rank of stakeholders groups' importance is set on the basis of the Stakeholder Index which is calculated according to the formula nr. 2. The values of the index are described in the following table.

Tab. 2: Stakeholder Index

\begin{tabular}{|l|r|r|}
\hline Generic Groups of Stakeholders & $\begin{array}{r}\text { Stakeholder } \\
\text { Index }\end{array}$ & Rank \\
\hline Departments of Regional Authority & 12,00 & 1. \\
\hline Municipalities & 10,00 & 2. \\
\hline Tourism Organizations & 9,00 & 3. \\
\hline Regional Development Agencies & 7,25 & 4. \\
\hline Destination Organizations & 6,50 & 5. \\
\hline Micro-regions & 5,00 & 6. \\
\hline
\end{tabular}

Source: own elaboration

Stakeholder Index enables to rank the stakeholders groups and aggregate them with regard to their importance. The primary role is played by the public administration, represented by the departments of the regional authority and the municipal offices of selected cities in the South Bohemia Region. However, the public administration alone is not able to successfully implement the strategy. It needs to involve the representatives of private sector as well. In this case the most important partners are the regional tourism organizations, and eventually the regional development agencies.

The described findings can be illustrated by the Stakeholder Circle which is shown on the picture nr. 1. The attribute of importance is represented by the size of the sector, attribute of proximity is represented by the distance of the sector from the center of the circle, and the attribute of urgency is represented by the depth (length) of the sector. The additional attribute of legitimacy is marked by the hatching of the sector.

\section{Pict. 1: Stakeholder Circle}

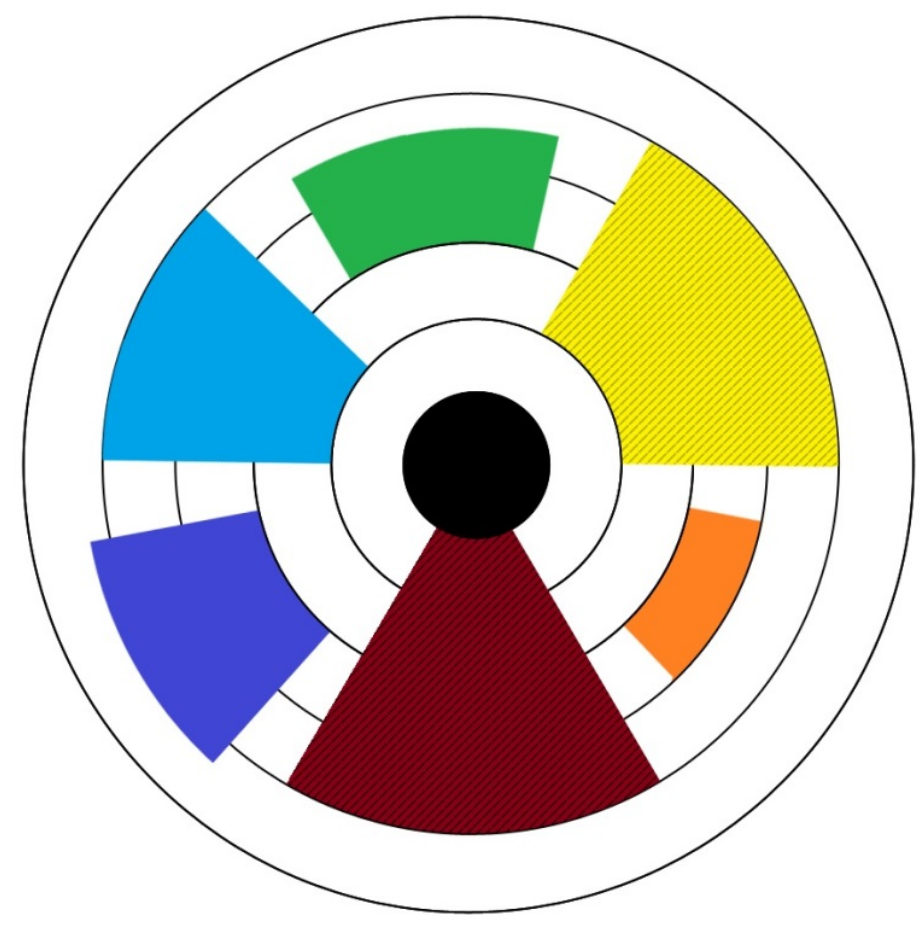

G1: Departments of Regional Authority

G2: Micro-regions

G3: Municipalities

G4: Destination Organizations

G5: Tourism Organizations

G6: Regional Development Agencies 
The additional information about the main links of cooperation between the South Bohemia Tourism Authority and the regional stakeholders was gathered within the performed survey. The South Bohemia Tourism Authority has close relationship to the other subjects from the sphere of public administration. The cooperation can be considered very intensive, based on the strong long-term ties. The cooperation is primarily focused on the creation of general conditions for tourism development in the region. From the point of view of the strategic priorities achievement, the partners from the sphere of public administration provide information about potential recipients of financial support and they serve as the administrators of the regional grant programmes. They participate in a monitoring of legislation and they apply a legislative marking process together with the regional authority. The public administration also support and initiate a formation of the new tourism products to some extent - e.g. in the form of participation in trade fairs, creation of product packages, advertising materials and sharing of good practices.

The most important partners from the private sector are the regional tourism organizations. Those subjects play an important role in a tourism market. The importance of their participation in tourism development is comparable to the importance of the municipalities. Within the strategy implementation process they provide valuable information about the development of tourism and they take part in defining the scope of the programmes for tourism development. The regional tourism organizations actively participate in monitoring of legislative proposals and they join the legislative marking process together with the South Bohemia Tourism Authority. These entities also organize an education of their members (entrepreneurs) by which they meet another strategic priority. They participate in a formation process of the new tourism products - e.g. they cooperate in the field of marketing and promotion, suggest new products, comment the suggestions of other stakeholders, and they serve as guarantees of products' quality simultaneously.

\section{Conclusion}

It is possible to claim that the drafted method of destination's stakeholder mapping has proved its fitness for use in practice. It was possible to characterize all the stakeholders groups, describe mutual links between the South Bohemia Tourism Authority and those groups, and assign the rank of the importance of the stakeholders. The aim of the introduction phase of the research was achieved. The information will be used within the consecutive research. It will enable us to analyze the real situation in the sphere of cooperation during the process of the tourism development strategy implementation.

The next phase of the research will be focused on more detailed survey of the scope and forms of cooperation with three key stakeholders groups in the South Bohemia Region. Its aim will be to reveal not only potential good practices and mutual links, but also the weaknesses in the cooperation process from the point of view of the key stakeholders groups. The complex Stakeholder Audit will be accomplished in this way. After finishing the testing phase the survey will be carried out in selected Czech and British regions. The British approach to the implementation process should serve as a main source of good practices for a quality improvement of cooperation between the regional stakeholders in the Czech Republic.

\section{Literature}

[1] BUHALIS, D. Marketing the competitive destination of the future. Tourism Management. 2000, vol. 21, no. 1. S. 97-116. ISSN 0261-5177.

[2] BYRD, E. T., CARDÉNAS, D. A., GREENWOOD, J. B. Factors of stakeholder understanding of tourism: The case of Eastern North Carolina. Tourism and Hospitality Research. 2008, vol. 8, no. 3. S 192-204. ISSN 1467-3584.

[3] COOPER, Ch. et al.. Tourism: Principles and Practice. Harlow: Pearson Education, 2008. ISBN 978-0-273-71126-1. 
[4] CROUCH, G. I.. Destination Competitiveness: An Analysis of Determinant Attributes. Journal of Travel Research. 2010, vol. 20, no. 10. S 1-19. ISSN 1552-6763.

[5] ČÁSTEK, O. Využití stakeholderského pristupu při strategické analýze podniku. Brno: Masarykova univerzita, 2010. ISBN 978-80-210-5411-0.

[6] DWYER, L., KIM, C. Destination Competitiveness: Determinants and Indicators. Current Issues in Tourism. 2003, vol. 6, no. 5. S. 369-414. ISSN 1368-3500.

[7] ENRIGHT, M. J., NEWTON, J. Determinants of Tourism Destination Competitiveness in Asia Pacific: Comprehensiveness and Universality. Journal of Travel Research. 2005, vol. 43, no. 4. S. 339-350. ISSN 1552-6763. DOI: 10.1177/0047287505274647.

[8] HALL, C. M. Tourism Planning: Policies, Processes and Relationships. Harlow: Prentice Hall, 2008. ISBN 978-0-13-204652-7.

[9] MEDEIROS DE ARAUJO, L., BRAMWELL, B. Stakeholder Assessment and Collaborative Tourism Planning: The Case of Brazil's Costa Dourada Project. Journal of Sustainable Tourism. 1999, vol. 7, no. 3-4. S. 356-378. ISSN 0966-9582.

[10] MITCHELL, R. K., AGLE, B. R., WOOD, D. J. Toward a Theory of Stakeholder Identification and Salience: Defining the Principle of Who and What Really Counts. The Academy of Management Review. 1997, vol. 22, no. 4. S 853-886. ISSN 0363-7425.

[11] NEJDL, K. Management destinace cestovního ruchu. Praha: Wolters Kluwer ČR, 2011. ISBN 978-80-7357-673-8.

[12] PECHLANER, H., SAUERWEIN, E. Strategy implementation in the Alpine tourism industry. International Journal of Contemporary Hospitality Management. 2002, vol. 14, no. 4. S. 157 168. ISSN 0959-6119. DOI: 10.1108/09596110210427003.

[13] POISTER T. H., STREIB, G. D. Strategic Management in the Public Sector: Concepts, Models, and Processes. Public Productivity \& Management Review. March 1999, vol. 22, no. 3. S. 308325. ISSN 1044-8039.

[14] RITCHIE, J. R. B., CROUCH, G. I. The competitive destination: a sustainable tourism perspective. Wallingford: CABI Publishing, 2003. ISBN 978-0-85199-664-6.

[15] TITTELBACHOVÁ, Š. Podpora rozvoje cestovního ruchu jako specifický nástroj regionální politiky. In Wokoun, R., Mates, P. (eds.) Management regionální politiky a reforma veřejné správy. Praha: Linde, 2006. S. 225-234. ISBN 80-7201-547-8.

[16] VACÍK, E. Význam strategického řízení pro organizace veřejné správy. In Vacek, J. (ed.) Moderní management ve veřejné správě. Plzeň: Západočeská univerzita v Plzni, 2006. S. 27-30. ISBN 80-7043-501-1.

[17] WALKER, D., SHELLEY, A., BOURNE, L. Influence, Stakeholder Mapping and Visualisation. Construction Management and Economics. 2008, vol. 26, no. 6. S. 645-658. ISSN 0144-6193.

[18] YOON, Y. Development of a Structural Model for Tourism Destination Competitiveness from Stakeholders' Perspectives. USA: Virginia Polytechnic Institute and State University, 2002.

\section{This paper was elaborated within the IGA 09/2013 project.}

